\title{
School as a Community Center: Impact of School-Family-Community Partnership in Student Education
}

\author{
Iris Mançi \\ Naim Frasheri High School, Durrës, Albania
}

\begin{abstract}
Schools, families, and the community today are facing a very important common challenge: Quality education for children and young people, and opportunities to respond to their needs beyond academic ones. The school center community has the initiative of the Convention on the Rights of the Child and the involvement of children is paramount. Children and young people are the active contributors to their well-being and development. Children have their own experiences and live in school contexts; they should be seen as agents of change, who analyze and take initiatives that provide a friendly school. School as a community center is a commitment to detaching school from its formal aspect. Run away from formalization implies opening the school to other social groups and a new form of cooperation with the community and specifically with parents. The essence of this structure is for the community to be closer to the school. This study aims to understand whether this partnership affects the development and education of students and young people. This study is focused on observing a middle school in the city of Durrës that follows this school model and browsing different literature. The findings of this study relate to the fact that the school sees what the most important needs of the students are and prepare a work plan for school students as well as children from the community (the case of learning foreign language English, etc.). This study comes with the next recommendations for schools as a community.
\end{abstract}

Keywords: community center school, students, teachers, family, community

The community center school is a friendly school where a school-family-community partnership is built to help develop the full potential of every school pupil. This concept of school is also supported by the Convention on the Rights of the Child where the child is placed in the center of attention in all the activities that are organized and implemented in the school. The school as a community center is a collaboration between the actors focusing on the academic development of all children, improving their achievements, family support, and community development. The main aim of this approach is the quality development of the school and the training of children and young people as citizens ready and able to contribute to their communities.

Today, school, family, and community face a common challenge: Quality education for children and young people, and opportunities to respond to their needs beyond the academic preparation. Successful studies and experiences have shown that when schools work in partnership with all other actors they create opportunities to overcome all barriers to learning leading to success. In this sense, the community center school aims to achieve the highest quality of education for each pupil.

Corresponding author: Iris Mançi, Msc., teacher, Naim Frasheri High School, Durrës, Albania; research fields: school, teachers, parents and pupil. 
Schools make an assessment of the pupils' needs, and then, they prepare a program for activities that will be developed to come to the aid of all pupils. School activities relate to the academic development of pupils; cultural, artistic, and sport development; and activities for family engagement and support as well as community engagement activities (IZHA, 2014).

\section{School Community Center}

\section{Roles of the Household}

Numerous studies point to the importance of the family environment where the child grows and develops. For this reason, the main factor for a positive development is the quality of relationships that are created within the family environment among members of each other, in particular, the attitude of parents to the child. The family is the child's first experience; it is also a normative system, in relation to the social and cultural system that regulates relationships with aspects outside it. The family serves as a transmitter to the child of a number of values and ideals, ways of thinking, and action of the society involved (Gjini, 1998, pp. 14-15).

Children from poor families read fewer books and spend more time in watching TV. They have less access to books, computers, and libraries and have less access to travel (Evans, 2004). One study found that poorer children had more problems in speaking, reading, mathematical skills, lack of knowledge of foreign language schools; this was due to lack of incentives at home (Korenman, Miller, \& Sjaastad, 1995).

All difficulties with the pupils are identified by the teachers of each subject and then a program of different activities will be developed for the children after the completion of the teaching process. The family environment has a major impact on the children's achievements. Parents are included in school by helping as a partner to solve different problems in the schools. Parents are like observers and advisers, giving their input to the parents' council and the parent council of the classroom where their child is.

\section{School Role}

The school is a social system that transmits values and influences the preservation of the social role and stability. The school through the function of education was to embody the values of individual achievement in the child. This value is very important for the functioning of society (Parson, 1959, pp. 291-313). The school through education plays a very important role in the socialization of children, preparing them for their role in society and for professional roles. Through education, children embody social rules that contribute to the functioning of society (Durkheim, 1956). The school seems to have been transformed into a closed institution and focused only on one function, that of teaching and learning. Many people saw this as an island isolated from the community. But today, the transformation of schools as a community center makes them functional and perceived as the institution where they interact, collaborate, and create. The school and the family, as two social institutions, pursue specific educational objectives by teaching children how to act and channel their interests.

Various studies in the field of education show the impact that the physical environment has on the learning process of the pupils. School design can influence the improvement or hinder the academic achievement of the pupils. Schools should create environments for the learner to be more active during the learning process and not have a passive classroom participation (Bingler, Quinn, \& Sullivan, 2003).

The impact of the school on the development of the pupils is realized in three main directions related to the learning process, the influence of the teachers, and the classmates of the class group. The learning process is defined as the integration of all information and knowledge, which is the principle of any development. Maria 
Montesori (1970) wrote that "the teacher should work in the service of the human being". According to her, child education is preparation for the future. The child is the center of the process, the actor of progress, and builder of the future. The teacher is the one who provides the service. He will bring all the instruments and materials necessary for the teaching process and the child will build his future. The child today is the future architect (Gjini, 2008, pp. 27-28).

Teachers play a key role in encouraging students to develop. He/she is responsible for organizing the lesson to ensure the highest level of pupil development. Peers are another element of the school and have an impact on the pupils and the relationships they create with each other in the school environment. The group of peers plays a very important role by preparing the pupils for the stage of their social development (Gjini, 1998, pp. 15-19).

\section{School-Family-Community Partnership}

The school is the key to the well-being and development of a country by educating children. The partner between these actors influences the improvement of the educational and parenting skills, creates a safer environment in the school, and helps to improve the curriculum and the results of the pupils. Many studies have shown that childhood, family, school, and community have a great impact on child development and growth. Social networks provide support to children, but the greater the social support during adolescence is, the greater the chance for this pupil to be successful in school is. The school through instruction, teaching, and various programs can strengthen the support system for young people in schools that come from poor families and minorities (Clark, 1991, p. 45). Many scholars have supported the idea that the work of the school is to continue the work started in the family.

Schools, families, and the community today face a common challenge: Quality education for children and young people, and opportunities to respond to their needs beyond academic preparation. Pupils should know and hold on the issues and social problems of their community. Partnership with the actors creates the opportunity to set up and implement projects with common themes, enabling the finding of ways to solve them and enabling students to contribute to their communities. Epstein and her colleagues have listed six strategies to help parents engage in education:

(1) Parental involvement is related to the fulfillment of the parent's basic responsibilities for the safety, health, and education of their children;

(2) Communication between school and households for school programs and the progress of children in parenting;

(3) Voluntary work of parents involved in sports and cultural and social activities of the school as well as assisting in different situations;

(4) Participation and support for the mine children at home by creating a suitable environment for the learning process at home;

(5) Participation of parents in decision-making in schools by involving school and class boards by supporting and contributing to school;

(6) Collaborating parents with the community and various organizations that support and enhance the children's opportunities to learn as cultural programs and other community services (Epstein et al., 2002, p. 17).

Successful studies and experiences have shown that when schools work in partnership with other actors create opportunities to overcome learning barriers leading to success. These schools are open to everyone and at 
all times and they are available to all members of the community. Schools provide many services, after class, for pupils, families, and the community. Schools focus on the academic, physical, social, and emotional development of the child, exploiting all the resources the family and community provides. In this sense, community center schools encourage to target higher quality. Mutual action of schools, families, and communities provides for all the needs of the children. School policies, teachers, and family activities have a very important impact on race, parenting, size, or family status (Epstein, 1992, p. 109).

\section{Methodology}

The research is based on quality scientific research, which helps us to achieve new results and knowledge. Based on the direct observation, the author has done in schools as a community center to observe closer to the functioning of the school in partnership with family and community. This qualitative method the author has used is tailored to meet the aims of this research. The author has also browsed different literature to form a theoretical framework in relation to the importance and impact that schools have as a community center for development at high levels of the child.

\section{Conclusions}

In schools as community centers, teachers are the main actors in this process. Teachers in every subject, such as literature, mathematics, biology, history, foreign languages, such as English, Italian, French, etc., during the learning process observe and make an assessment of the needs of the children. When teachers identify all pupils' needs, they begin to prepare a lesson plan that is affordable for those students who come from families who have no economic opportunity, minorities, or pupils who have difficulty in learning.

In the case of foreign language learning, in addition to pupils who are in the school in these lessons are included children who come from families that have no economic opportunities from the community. During these classes, all children get more new knowledge or acquire the information they have learned before. With the realization of some teaching hours, the teachers make an assessment of student achievement over those hours they have attended.

After the end of the lesson, the school sports fields are open so that they can use the community to develop various sports activities, such as football, basketball, or volleyball. It is noticed that the results of the students attending these lessons are higher than before. Collaboration between the three main elements, such as family, school, and community, affects the improvement of four key areas related to (Blank, Melaville, \& Shah, 2003):

(1) Pupils' learning is related to academic achievement and development and social skills to interact with society;

(2) The effectiveness of the school focuses on the relationship between the parents and the middle class who becomes stronger. This has the effect of creating a positive climate and security in school environments and wider support for the community;

(3) The engagement of the family shows greater stability. Parents have more frequent communication with teachers and are more involved in the activities organized by the school;

(4) Community visibility is linked to the best relationship between students and residents by creating a safer environment. 


\section{References}

Bingler, S., Quinn, L., \& Sullivan, K. (2003). School as centers of community: A Citizen's guide for planning and design. Washington, D.C.: National Clearinghouse for Educational Facilities.

Blank, M. J., Melaville, A., \& Shah, B. P. (2003). Making the difference: Research and practice in community schools. Washington, D.C.: Institute for Educational Leadership, Coalition for Community Schools.

Clark, M. (1991), Social identity, peer relations, and academic competence of African-American adolescents. Education and Urban Society, 24(1), 41-52.

Durheim, E. (1956). Education and society. Glencoe: Free Press.

Epstein, J. (1992). School and family partnership. In A. Marvin (Ed.), Encyclopedia of educational research (6th ed., pp. 1139-1151). New York: MacMillan.

Epstein, J. L., Sanders, M. G., Simon, B. S., Salinas, K. C., Jansorn, N. R., \& Van Voorhis, F. L. (2002). School, family, and community partnership: Your handbook for action. Thausand Oaks, Ca.: Corwin Press, Inc.

Evans, G. W. (2004). The environment of childhood poverty. American Psychologist, 59, 77-92.

Gjini, F. (1998). Nxënësi dhe grupi (The student and the group). Elbasan: Sejko.

Gjini, F. (2008). Drejt edukimit të një humanizmi të ri. Modele, metoda dhe teori në ndihmë të studentëve, mësuesve dhe prindërve (Towards the education of a new humanity. Models, methods and theories to help students, teachers and parents). Elbasan: Ylli.

IZHA. (2014). Udhëzues për shkollat qendra komunitare (Guide to community schools). Retrieved from http://myschool.al/ resources/programe/doc2.pdf

Korenman, S., Miller, J. E., \& Sjaastad, J. E. (1995). Long-term poverty and child development in the United States: Results from the NLSY. Children and Youth Services Review, 17, 127-155.

Montesori, M. (1970). La pedagogie scientifique (1909 et 1916) [Scientific pedagogy (1909 and 1916)]. Paris: ESF.

Parsons, T. (1959). The schoolclass as a social system: Some of its functions in American society. Harvard Educational Review, 29, 291-313. 